\title{
Geochemistry of tetrahedrite group minerals and associated silver paragenesis in the Boguszów baryte deposit, Poland
}

\author{
Sławomir MEDERSKI ${ }^{1, *}$, Jaroslav PRŠEK ${ }^{1}$ and Żaneta NIEMASZ ${ }^{1}$ \\ 1 AGH University of Science and Technology, al. A. Mickiewicza 30, 30-059 Kraków, Poland
}

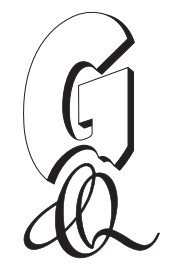

Mederski, S., Pršek J., Niemasz, Ż., 2020. Geochemistry of tetrahedrite group minerals and associated silver paragenesis in the Boguszów baryte deposit, Poland. Geological Quarterly, 64 (4): 958-968, doi: 10.7306/gq.1562

Associate Editor: Jacek Szczepański

Primary ore mineralization in the abandoned Boguszów baryte-polymetallic deposit, located in the Intra-Sudetic Depression, was studied by reflected light microscopy and electron microprobe. Ore minerals, occurring as veinlets, irregular aggregates and lenses in baryte veins are hosted by the Upper Carboniferous Chełmiec rhyodacite laccolith. They are dominated by galena, sphalerite (with $\mathrm{Cd}$ up to $0.04 \mathrm{apfu}$ ) and tetrahedrite group minerals (TGM). Four generations of the TGM were distinguished according to textural features and Ag content: (1) low-Ag tetrahedrite-(Zn) (Ag: 0.22-0.6 apfu), (2) Ag-enriched tetrahedrite-(Zn) and Ag-enriched tetrahedrite-(Fe) (Ag: 0.71-1.45 apfu), (3) members of the freibergite series: "freibergite-(Fe)" and "freibergite-(Zn)" (Ag: 3.21-3.48 apfu; Hg: up to 0.75 apfu), (4) member of the "freibergite-(Fe)" series (Ag: 5.32-5.78 apfu). Several elongated inclusions of Ag-bearing sulphosalts within galena crystals were observed (members of the series "freibergite-(Fe)" and "freibergite-(Zn)", pyrargyrite and polybasite). These polymetallic silver-bearing ores were mined in Boguszów from the 15th to the 19th century. Additionally, small grains of cobalt-enriched löllingite and gersdorffite were observed, which were formed from fluids sourced from the ultramafic basement. The textural characteristics of the ore, the mineral paragenesis and the chemical composition of individual ore minerals indicate low-temperature crystallization conditions.

Key words: Boguszów, baryte veins, silver mineralization, tetrahedrite.

\section{INTRODUCTION}

Silver mineralization in the form of silver minerals, tetrahedrite group minerals (TGM) or in the form of admixtures in galena or bornite is common in different genetic types of base metal deposits. It occurs primarily in epithermal systems (e.g., Gemmell et al., 1989; Plumlee and Whitehouse-Veaux, 1994; Cheilletz et al., 2002; Sack and Goodell, 2002; Sack et al., 2003; Bestemianova and Grinev, 2017). In these systems, baryte is a major gangue mineral phase. The presence of silver mineralization is also recorded in other deposit types, including skarn, volcanogenic massive sulphide, sedimentaryexhalative and sediment-hosted type deposits (e.g., Grossou-Valta et al., 1990; Höller and Gandhi, 1995; Shalaby et al., 2004; Kołodziejczyk et al., 2016; Kozub-Budzyń and Piestrzyński, 2018).

Occurrences of silver-bearing mineralization are quite common in the area of Sudetes Mountains in Poland (Lis and

* Corresponding author, e-mail: mederski@agh.edu.pl Received: June 1, 2020; accepted: September 8, 2020; first published online: October 14, 2020
Sylwestrzak, 1986). The Ag-mineralization occurrences recorded in the literature are shown in Table 1. More Ag deposits and occurrences, as well as opportunities for comparison, can be observed within the Bohemian Massif in the Czech Republic. This area is famous for its numerous silver deposits mined in previous centuries, some of which are summarised in Table 2.

In the Boguszów baryte deposit only proustite has been noted without precise identification (Traube, 1888), as well as tetrahedrite with 3 wt.\% Ag (Migaszewski, 1972). For many years silver ores were exploited in baryte veins in the Boguszów area. However, no quantitative results concerning the Ag-mineralization are available in the literature. This study describes the silver mineralization in the baryte veins and to provide precise chemical data on the silver minerals, especially for the TGM from the Boguszów baryte deposit.

\section{LOCALITY AND GEOLOGICAL SETTING}

The Boguszów baryte vein deposit (Segen Gottes Mine) is located on the south-west side of Chełmiec Hill (Fig. 1A), $\sim 6 \mathrm{~km}$ to the west of Wałbrzych, close to the town of Boguszów Gorce. The baryte deposit is located in the Wałbrzych Depression, which is part of the fault-bounded, NW-SE trending IntraSudetic Depression, at the northern periphery of the Bohemian 


\section{Ag-mineralization occurrences in the Sudetes Mountains}

\begin{tabular}{|c|c|c|c|}
\hline $\begin{array}{c}\text { Locality } \\
\text { (type of mineralization) }\end{array}$ & Silver mineralization and Ag-enriched TGM & $\begin{array}{c}\text { Generalized associated } \\
\text { mineralization }\end{array}$ & References \\
\hline $\begin{array}{l}\text { Grudno: } \\
\text { hydrothermal quartz- } \\
\text { calcite-sulphide vein }\end{array}$ & $\begin{array}{c}\text { freibergite }\left[\mathrm{Ag}_{6}\left(\mathrm{Cu}_{4} \mathrm{Fe}_{2}\right) \mathrm{Sb}_{4} \mathrm{~S}_{13}\right] \\
\text { pyrargyrite }\left[\mathrm{Ag}_{3} \mathrm{SbS}_{3}\right]\end{array}$ & $\begin{array}{c}\text { quartz, calcite, arsenopyrite, pyrite, } \\
\text { sphalerite, TGM, chalcopyrite, Cu, } \\
\text { Pb, Sb minerals }\end{array}$ & $\begin{array}{l}\text { Paulo and } \\
\text { Salamon (1974a) }\end{array}$ \\
\hline $\begin{array}{l}\text { Radzimowice: } \\
\text { hydrothermal polymetallic } \\
\text { veins }\end{array}$ & $\begin{array}{c}\text { freibergite }\left[\mathrm{Ag}_{6}\left(\mathrm{Cu}_{4} \mathrm{Fe}_{2}\right) \mathrm{Sb}_{4} \mathrm{~S}_{13}\right], \text { acanthite } \\
{\left[\mathrm{Ag}_{2} \mathrm{~S}\right], \text { gustavite }\left[\mathrm{AgPbBi} \mathrm{S}_{6}\right], \text { treasurite }} \\
{\left[\mathrm{Ag}_{7} \mathrm{~Pb}_{6} \mathrm{Bi}_{15} \mathrm{~S}_{32}\right], \text { hessite }\left[\mathrm{Ag}_{2} \mathrm{Te}\right]} \\
\text { electrum }[\mathrm{Au}, \mathrm{Ag}]\end{array}$ & $\begin{array}{c}\text { quartz, dolomite, calcite, siderite, } \\
\text { ankerite, baryte, pyrite, arsenopy- } \\
\text { rite, chalcopyrite, galena, } \\
\text { sphalerite, TGM, different sulphides } \\
\text { and sulphosalts }\end{array}$ & $\begin{array}{l}\text { Manecki (1965); } \\
\text { Paulo and } \\
\text { Salamon (1974b); } \\
\text { Mikulski (2005) }\end{array}$ \\
\hline $\begin{array}{l}\text { Kletno: } \\
\text { polymetallic Cu-Ag-U-Se } \\
\text { mineralization }\end{array}$ & $\begin{array}{c}\text { native silver, stromeyerite }[\mathrm{AgCuS}] \\
\text { miargyrite }\left[\mathrm{AgSbS} \mathrm{A}_{2}\right], \text { argentite }\left[\mathrm{Ag}_{2} \mathrm{~S}\right] \\
\text { matildite }\left[\mathrm{AgBiS} \mathrm{S}_{2}\right], \text { naumannite }\left[\mathrm{Ag}_{2} \mathrm{Se}\right] \\
\text { bohdanowiczite }\left[\mathrm{AgBiSe}_{2}\right]\end{array}$ & $\begin{array}{l}\text { quartz, baryte, fluorite, calcite, } \\
\text { uraninite, Fe oxides, Fe, Cu, Pb, } \\
\text { Zn, Hg sulphides, bismuth } \\
\text { sulphosalts }\end{array}$ & $\begin{array}{c}\text { Banaś and } \\
\text { Mochnacka (2000) }\end{array}$ \\
\hline $\begin{array}{c}\text { Kowary: } \\
\text { magnetite-ura- } \\
\text { nium-polymetallic mineraliza- } \\
\text { tion in veins and nests }\end{array}$ & $\begin{array}{l}\text { native silver }[\mathrm{Ag}], \text { stromeyerite }[\mathrm{AgCuS}] \\
\text { proustite }\left[\mathrm{Ag}_{3} \mathrm{As} \mathrm{S}_{3}\right], \text { argentite }\left[\mathrm{Ag}_{2} \mathrm{~S}\right] \\
\text { pyrargyrite }\left[\mathrm{Ag}_{3} \mathrm{SbS}\right], \text { matildite }\left[\mathrm{AgBiS}_{2}\right]\end{array}$ & $\begin{array}{l}\text { calcite, dolomite, Fe oxides, } \\
\text { uraninite, Fe, } \mathrm{Cu}, \mathrm{Pb}, \mathrm{Zn}, \mathrm{Bi} \\
\text { sulphides and sulphosalts }\end{array}$ & $\begin{array}{l}\text { Mochnacka and } \\
\text { Banaś (2000) }\end{array}$ \\
\hline $\begin{array}{l}\text { Redziny: } \\
\text { polymetallic mineralization } \\
\text { in quartz veins and dissemi- } \\
\text { nated in schists and } \\
\text { amphibolites }\end{array}$ & $\begin{array}{c}\text { freibergite }\left[\mathrm{Ag}_{6}\left(\mathrm{Cu}_{4} \mathrm{Fe}_{2}\right) \mathrm{Sb}_{4} \mathrm{~S}_{13}\right] \\
\text { Ag-rich tetrahedrite (up to } 15.9 \text { wt. } \% \mathrm{Ag} \text { ) }\end{array}$ & $\begin{array}{c}\text { arsenopyrite, cassiterite, pyrite, } \\
\text { pyrrhotite, chalcopyrite, cubanite, } \\
\text { galena, sphalerite, bismuth } \\
\text { sulphides and sulphotellurides, } \\
\text { TGM, Ag(Cu)-Pb-Bi(Sb) } \\
\text { sulphosalts, Sn-bearing sulphides }\end{array}$ & $\begin{array}{l}\text { Gołębiowska et al. } \\
(2012)\end{array}$ \\
\hline $\begin{array}{l}\text { Czarnów: } \\
\text { polymetallic veins }\end{array}$ & $\begin{array}{c}\text { argentite }\left[\mathrm{Ag}_{2} \mathrm{~S}\right], \text { matildite }\left[\mathrm{AgBiS} \mathrm{S}_{2}\right], \text { treasurite } \\
{\left[\mathrm{Ag}_{7} \mathrm{~Pb}_{6} \mathrm{Bi}_{15} \mathrm{~S}_{32}\right], \text { hessite }\left[\mathrm{Ag}_{2} \mathrm{Te}\right]} \\
\mathrm{Ag}-\mathrm{Bi} \text { sulphotellurides }\end{array}$ & $\begin{array}{l}\text { quartz, calcite, dolomite, arsenopy- } \\
\text { rite, chalcopyrite, pyrrhotite, pyrite, } \\
\text { galena, sphalerite, stibnite, cassit- } \\
\text { erite and other Cu-Bi sulphides and } \\
\text { sulphosalts }\end{array}$ & Mikulski (2010) \\
\hline $\begin{array}{l}\text { Ciechanowice: } \\
\text { polymetallic veins }\end{array}$ & $\begin{array}{c}\text { acanthite }\left[\mathrm{Ag}_{2} \mathrm{~S}\right], \mathrm{Ag} \text {-amalgams, eugenite } \\
{\left[\mathrm{Ag}_{11} \mathrm{Hg}_{2}\right], \text { native } \mathrm{Ag} \text {, stromeyerite }[\mathrm{AgCuS}]} \\
\text { argentite }\left[\mathrm{Ag}_{2} \mathrm{~S}\right], \text { stephanite }\left[\mathrm{Ag}_{5} \mathrm{SbS}_{4}\right] \\
\text { xanthoconite }\left[\mathrm{Ag}_{3} \mathrm{AsS} \mathrm{S}_{3}\right], \text { proustite }\left[\mathrm{Ag}_{3} \mathrm{AsS} \mathrm{S}_{3}\right] \\
\text { polybasite }\left[\mathrm{Cu}(\mathrm{Ag}, \mathrm{Cu})_{6} \mathrm{Ag}_{9} \mathrm{Sb}_{2} \mathrm{~S}_{11}\right]\end{array}$ & $\begin{array}{l}\text { baryte, calcite, ankerite, löllingite, } \\
\text { safflorite, bornite, chalcocite, TGM }\end{array}$ & Siuda (2012) \\
\hline $\begin{array}{l}\text { Przecznica, Gierczyn: } \\
\text { disseminated and vein-type } \\
\text { cassiterite-polymetallic } \\
\text { mineralization in } \\
\text { chlorite-mica-quartz schists }\end{array}$ & $\begin{array}{l}\text { pyrargyrite }\left[\mathrm{Ag}_{3} \mathrm{SbS}_{3}\right] \text { : Gierczyn and } \\
\text { Przecznica, Ag-rich tetrahedrite } \\
(28-29 \text { wt.\% Ag): Przecznica }\end{array}$ & $\begin{array}{c}\text { quartz, mica, chlorites, cassiterite, } \\
\text { pyrrhotite, sphalerite, chalcopyrite } \\
\text { and different sulphides, arsenides } \\
\text { and sulphosalts }\end{array}$ & $\begin{array}{l}\text { Piestrzyński and } \\
\text { Mochnacka (2003) }\end{array}$ \\
\hline $\begin{array}{l}\text { Dziećmorowice - Stary } \\
\text { Julianów: } \\
\text { hydrothermal poly- } \\
\text { metallic-baryte-quartz- } \\
\text {-calcite veins }\end{array}$ & $\begin{array}{c}\text { freibergite }\left[\mathrm{Ag}_{6}\left(\mathrm{Cu}_{4} \mathrm{Fe}_{2}\right) \mathrm{Sb}_{4} \mathrm{~S}_{13}\right] \\
\text { stephanite }\left[\mathrm{Ag}_{5} \mathrm{SbS}_{4}\right]\end{array}$ & $\begin{array}{c}\text { baryte, quartz, calcite, galena, } \\
\text { sphalerite, TGM, niccolite, smaltite, } \\
\text { cobaltite, pyrite, chalcopyrite, } \\
\text { arsenopyrite, magnetite, uraninite }\end{array}$ & $\begin{array}{l}\text { Petrascheck } \\
(1933)\end{array}$ \\
\hline $\begin{array}{c}\text { Zagórze Śląskie: } \\
\text { hydrothermal } \\
\text { polymetallic-baryte veins }\end{array}$ & argentopentlandite $\left[\mathrm{Ag}(\mathrm{Fe}, \mathrm{Ni})_{8} \mathrm{~S}_{8}\right]$ & $\begin{array}{l}\text { baryte, chalcopyrite, galena, } \\
\text { sphalerite, pyrrhotite }\end{array}$ & $\begin{array}{l}\text { Piestrzyński and } \\
\text { Kowalik (2015) }\end{array}$ \\
\hline $\begin{array}{l}\text { Bystrzyca Górna: } \\
\text { hydrothermal Ag-rich } \\
\text { baryte-quartz veins }\end{array}$ & $\begin{array}{c}\text { pyrargyrite }\left[\mathrm{Ag}_{3} \mathrm{SbS}_{3}\right], \text { stephanite }\left[\mathrm{Ag}_{5} \mathrm{SbS}_{4}\right] \\
\text { miargyrite }\left[\mathrm{AgSbS}_{2}\right], \text { argentite }\left[\mathrm{Ag}_{2} \mathrm{~S}\right], \\
\text { dyscrasite }\left[\mathrm{Ag}_{3} \mathrm{Sb}\right], \mathrm{Ag} \text {-rich tetrahedrite, } \\
\text { freibergite }\left[\mathrm{Ag}_{6}\left(\mathrm{Cu}_{4} \mathrm{Fe}_{2}\right) \mathrm{Sb}_{4} \mathrm{~S}_{13}\right], \text { zoubekite } \\
{\left[\mathrm{AgPb}_{4} \mathrm{Sb}_{4} \mathrm{~S}_{10}\right], \text { freiselbenite }\left[\mathrm{AgPbSbS} \mathrm{Pb}_{3}\right]} \\
\text { andorite VI }\left[\mathrm{AgPbSb} \mathrm{S}_{6}\right]\end{array}$ & $\begin{array}{c}\text { baryte, quartz, galena, sphalerite, } \\
\text { greenockite, chalcopyrite, TGM, } \\
\text { bournonite, native antimony, } \\
\text { Pb-Sb sulphosalts }\end{array}$ & Pršek et al. (2019) \\
\hline $\begin{array}{l}\text { Boguszów: } \\
\text { hydrothermal Ag-rich } \\
\text { baryte veins }\end{array}$ & $\begin{array}{c}\text { Ag-enriched tetrahedrite-(Fe) and } \\
\text { tetrahedrite- }(\mathrm{Zn})(6.20 \text { to } 9.08 \mathrm{wt} \% \% \mathrm{Ag}), \\
\text { member of series "freibergite-( } \mathrm{Fe}) \text { " and } \\
\text { "freibergite-( } \mathrm{Zn}) \text { ", pyrargyrite }\left[\mathrm{Ag}_{3} \mathrm{SbS}_{3}\right] \\
\text { polybasite }\left[\mathrm{Cu}(\mathrm{Ag}, \mathrm{Cu})_{6} \mathrm{Ag}_{9} \mathrm{Sb}_{2} \mathrm{~S}_{11}\right]\end{array}$ & $\begin{array}{l}\text { baryte, quartz, carbonates, galena, } \\
\text { sphalerite, TGM, chalcopyrite, py- } \\
\text { rite, löllingite, gersdorffite, fluorite }\end{array}$ & $\begin{array}{l}\text { Traube (1888); } \\
\text { this study }\end{array}$ \\
\hline
\end{tabular}

Massif (Żelaźniewicz et al., 2011). The depression is filled with Carboniferous sediments: Culm facies (conglomerates and greywackes), Wałbrzych and Biały Kamień units (coal-bearing lithostratigraphic units; Dziedzic, 1971; Mastalerz, 1996; Kurowski, 1998). The sedimentary succession is divided by the Upper Carboniferous Chełmiec rhyodacite laccolith of Westphalian B/C transition age (310 $\pm 4 \mathrm{Ma})$ (Grocholski, 1965; Mastalerz and Mastalerz, 2000; Awdankiewicz and Kryza, 2010). The Boguszów baryte deposit is closely related to the NW-SE trending (strike-slip) fault-zone observed in the NW part of the Chełmiec dome (Gruszczyk, 1952). Several baryte veins (Fig. 1B) formed as a result of epithermal activity at a late stage of the subvolcanic activity and these veins cut the Chelmiec laccolith and the surrounding sedimentary units (Gruszczyk et al., 1970).

In the Boguszów deposit, three main mineral assemblages related to baryte veins are observed: baryte-sulphides, barytefluorite and baryte-quartz (Gruszczyk, 1952). However, Paulo (1994) distinguished five ore mineralization stages there:

- quartz with Zn, Ag, Cu, Pb (minor As, Fe, Ni, Bi) sulphides;

- carbonates and hematite $(\mathrm{Cu}, \mathrm{Pb}$ sulphides);

- baryte and fluorite ( $\mathrm{Pb}$, minor $\mathrm{Cu}$ and $\mathrm{Zn}$ sulphides);

- quartz, locally marcasite;

- fluorite leaching, oxidation, transparent baryte overgrowths. 
Selected Ag-mineralization occurrences in the Bohemian Massif

\begin{tabular}{|c|c|c|c|}
\hline $\begin{array}{c}\text { Locality } \\
\text { (type of mineralization) }\end{array}$ & Silver mineralization and Ag-enriched TGM & $\begin{array}{c}\text { Generalized associated } \\
\text { mineralization }\end{array}$ & References \\
\hline $\begin{array}{l}\text { Kutná Hora: } \\
\text { hydrothermal ore veins }\end{array}$ & 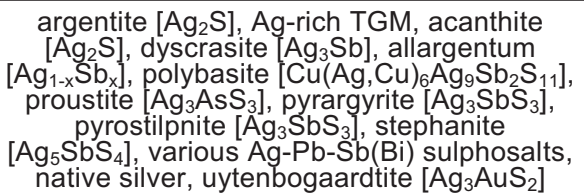 & $\begin{array}{l}\text { quartz, kutnahorite, galena, } \\
\text { various } \mathrm{Ag}-\mathrm{Pb}-\mathrm{Sb}(\mathrm{Bi}) \text { sulphosalts }\end{array}$ & $\begin{array}{l}\text { Pažout et al. } \\
(2017,2019)\end{array}$ \\
\hline $\begin{array}{c}\text { Řepová near Mohelnice: } \\
\text { polymetallic baryte-carbonate } \\
\text { veins }\end{array}$ & $\begin{array}{c}\text { tetrahedrite (up to } 16.4 \text { wt.\% } \mathrm{Ag}), \text { freibergite } \\
{\left[\mathrm{Ag}_{6}\left(\mathrm{Cu}_{4} \mathrm{Fe}_{2}\right) \mathrm{Sb}_{4} \mathrm{~S}_{13}\right], \mathrm{Ag}_{2}-a m a l g a m s} \\
\text { acanthite }\left[\mathrm{Ag}_{2} \mathrm{~S}\right]\end{array}$ & $\begin{array}{c}\text { baryte, dolomite, ankerite, siderite, } \\
\text { quartz, galena, sphalerite, } \\
\text { cinnabar, chalcopyrite, Ni-Ċo } \\
\text { phases, native Au }\end{array}$ & $\begin{array}{l}\text { Dolníček et al. } \\
(2019 a)\end{array}$ \\
\hline $\begin{array}{l}\text { Horní Město: } \\
\text { Ag mineralized veins in a } \\
\text { stratiform base metal deposit }\end{array}$ & $\begin{array}{c}\text { native } \mathrm{Ag} \text {, proustite }\left[\mathrm{Ag}_{3} \mathrm{AsS}_{3}\right], \text { pyrargyrite } \\
{\left[\mathrm{Ag}_{3} \mathrm{SbS}_{3}\right], \text { stephanite }\left[\mathrm{Ag}_{5} \mathrm{SbS}_{4}\right], \text { miargyrite }} \\
{\left[\mathrm{AgSb} \mathrm{S}_{2}\right] \text {, allargentum }\left[\mathrm{Ag}_{1-\mathrm{x}} \mathrm{Sb}_{\mathrm{x}}\right]} \\
\text { Ag-rich tennantite (up to } 14 \text { wt.\% } \mathrm{Ag} \text { ), } \\
\text { Ag-rich tetrahedrite (up to } 17.5 \text { wt.\% Ag) }\end{array}$ & $\begin{array}{l}\text { K-feldspar, quartz, calcite, apatite, } \\
\text { rutile, pyrite, arsenopyrite }\end{array}$ & $\begin{array}{l}\text { Dolníček et al. } \\
(2019 b)\end{array}$ \\
\hline $\begin{array}{l}\text { Havlíčkův Brod: } \\
\text { quartz-carbonate veins }\end{array}$ & $\begin{array}{c}\text { freibergite }\left[\mathrm{Ag}_{6}\left(\mathrm{Cu}_{4} \mathrm{Fe}_{2}\right) \mathrm{Sb}_{4} \mathrm{~S}_{13}\right], \text { pyrargyrite } \\
{\left[\mathrm{Ag}_{3} \mathrm{SbS}_{3}\right], \text { miargyrite }\left[\mathrm{AgSbS}_{2}\right] \text {, andorite } \mathrm{VI}} \\
{\left[\mathrm{AgPbSb}_{3}\right] \text {, native } \mathrm{Ag} \text {, argentite }\left[\mathrm{Ag}_{2} \mathrm{~S}\right]}\end{array}$ & $\begin{array}{l}\text { quartz, carbonates, galena, } \\
\text { boulangerite, bournonite, } \\
\text { arsenopyrite, sphalerite, } \\
\text { berthierite, jamesonite }\end{array}$ & $\begin{array}{l}\text { Sejkora et al. } \\
(2015)\end{array}$ \\
\hline $\begin{array}{c}\text { Skalka near Kraslice: } \\
\text { quartz-siderite-Pb-Zn-Cu } \\
\text { sulphide lenses }\end{array}$ & Ag-rich tetrahedrite (up to $18.2 \mathrm{wt} \% \mathrm{Ag}$ ) & $\begin{array}{l}\text { quartz, siderite, jamesonite, } \\
\text { sphalerite, bournonite, } \\
\text { boulangerite, ullmannite }\end{array}$ & $\begin{array}{l}\text { Sejkora et al. } \\
(2016)\end{array}$ \\
\hline $\begin{array}{c}\text { Komárovice: } \\
\text { baryte } \pm \text { quartz-calcite veins }\end{array}$ & $\begin{array}{c}\text { pyrargyrite }\left[\mathrm{Ag}_{3} \mathrm{SbS}_{3}\right] \\
\text { freibergite }\left[\mathrm{Ag}_{6}\left(\mathrm{Cu}_{4} \mathrm{Fe}_{2}\right) \mathrm{Sb}_{4} \mathrm{~S}_{13}\right]\end{array}$ & baryte, quartz, calcite, galena & Hrazdil et al. (2012) \\
\hline
\end{tabular}

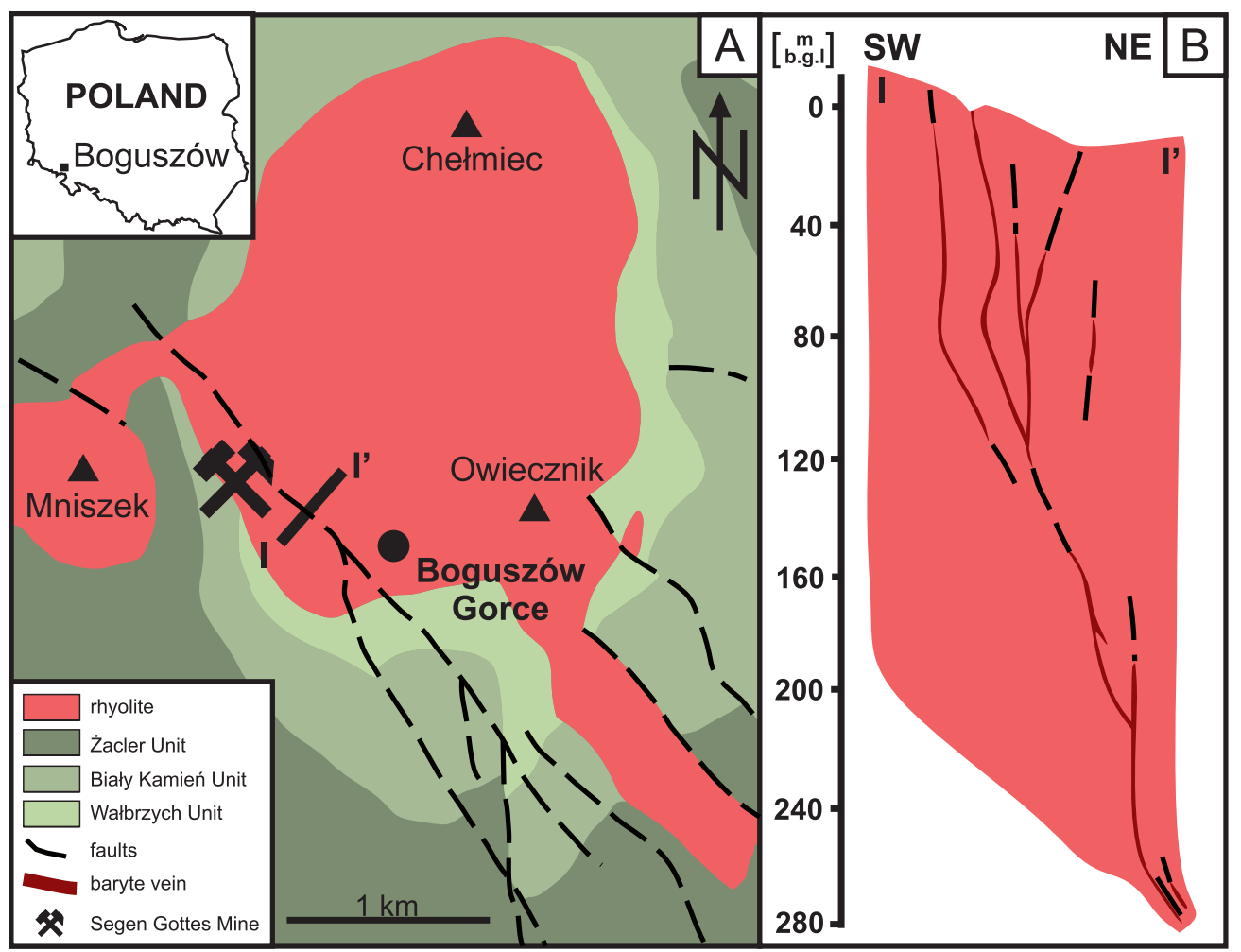

Fig. 1A - simplified geological map of the Boguszów area;

1B - cross-section of baryte veins (modified from Gruszczyk et al., 1970)

Migaszewski (1972) studied and described different ore minerals from the hydrothermal veins (partly with baryte) and ore minerals located in the hydrothermally altered volcanic rocks: pyrite, sphalerite, tetrahedrite, chalcopyrite, galena, cobaltite and uraninite.
Mining activity in the Boguszów area dates back to the 15th century, when silver-rich baryte-galena-tetrahedrite ores were exploited. Initially, the work was carried out by open pit methods. The first underground mine was opened in 1530 (Gruszczyk, 1952). Mining took place until 1755, when the lo- 
cal mining authority in Boguszów was closed. Between 1856 and 1865 , local mining for silver ores was attempted with no positive result. However, attention was drawn to the presence of baryte (Gruszczyk, 1952), which was mined from the Boguszów deposit until 1997.

\section{MATERIALS AND METHODS}

Ore samples were collected in the old dumps close to Segen Gottes Mine in Boguszów. Samples were carefully checked macroscopically and $>20$ ore textures were chosen for microscopic study. Only samples containing silver mineralization were chosen for EPMA analysis. Silver minerals, main sulphides and sulpharsenides, were analysed using the JEOL Super Probe 8230 in the Laboratory of Critical Elements at the Faculty of Geology Geophysics and Environmental Protection, AGH-UST, Kraków Poland. The following operating conditions and standards were used: accelerating voltage $20 \mathrm{kV}$, beam current $20 \mathrm{nA}$ (for sulphides and sulpharsenides) and beam current $10 \mathrm{nA}$ (for Ag minerals), peak time 10-20 s, background time $10 \mathrm{~s}$ ( $5 \mathrm{~s}$ for Ag minerals) and a beam diameter $5 \mu \mathrm{m}$. The following wavelengths (to omit interferences between the element spectral lines) were used: $\operatorname{CdL} \alpha, \mathrm{ZnK} \alpha, \mathrm{CuK} \alpha, \mathrm{SK} \alpha$, $\mathrm{SnL} \alpha, \mathrm{HgM} \alpha$, FeK $\alpha, \mathrm{MnK} \alpha, \mathrm{AgL} \alpha$, AsL $\alpha, \operatorname{SbL} \alpha, \operatorname{BiM} \alpha$, TeL $\alpha$, $\mathrm{PbM} \alpha, \operatorname{SeL} \alpha, \mathrm{NiK} \alpha, \mathrm{CoK} \alpha$ (for sulphides and sulpharsenides); $\mathrm{SK} \alpha, \mathrm{CuK} \alpha, \mathrm{BiM} \alpha, \mathrm{AgL} \alpha$, SbL $\alpha$, SeL $\alpha$, AsL $\alpha$ (for Ag minerals); $\mathrm{BiM} \alpha, \mathrm{SbL} \alpha, \mathrm{ZnK} \alpha, \mathrm{CuK} \alpha, \mathrm{SK} \alpha, \mathrm{HgM} \alpha, \mathrm{FeK} \alpha, \mathrm{AgL} \alpha$, and AsL $\alpha$ for tetrahedrite. Natural mineral standards $\left(\mathrm{FeS}_{2}, \mathrm{ZnS}\right.$, $\mathrm{PbS}$ ) and synthetic compounds (CdS, InAs, MnS, HgTe, PbTe, $\mathrm{Sb}_{2} \mathrm{~S}_{3}, \mathrm{Cu}, \mathrm{Ag}, \mathrm{Bi}, \mathrm{Ni}, \mathrm{Co}, \mathrm{Se}$ ) were used for calibration. All interferences between the element spectral lines were calculated using autocorrections based on standards. The detection limits for analysed elements were as follows: for sulphides and sulpharsenides S - 0.01 wt. \%, Zn - 0.03 wt. \%, Fe - 0.03 wt. \%, $\mathrm{Cu}-0.02$ wt. \%, Ag - 0.02 wt. \%, Cd - 0.02 wt.\%, Hg - 0.02 wt. \%, Co - 0.02 wt. \%, for Ag minerals S - 0.02 wt. $\%, \mathrm{Sb}-0.09$ wt. $\%$, As - 0.12 wt. \%, Cu - 0.05 wt. \%, Ag - 0.35 wt. \%, Bi - 0.06 wt. \%, for tetrahedrite S - 0.02 wt. $\%, \mathrm{Sb}-0.07$ wt. $\%$, As -0.01 wt. $\%$, Cu 0.04 wt. $\%, \mathrm{Ag}-0.02$ wt. \%, Zn - 0.04 wt. \%, Fe - 0.03 wt. \%, Hg 0.06 wt. $\%, \mathrm{Bi}-0.05$ wt. $\%$.

\section{RESULTS}

The main ore minerals in the samples studied are galena, sphalerite, tetrahedrite, pyrite and chalcopyrite (Fig. 2). Galena and sphalerite form small veinlets up to $1 \mathrm{~cm}$ in laminated baryte, as well as irregular aggregates up to several centimetres across in baryte breccia. Low-Ag tetrahedrite was also found as aggregates up to $1 \mathrm{~cm}$ in size disseminated in highly altered volcanic rocks or in baryte. Ag minerals and Ag-rich TGM mostly form inclusions or veinlets in galena up to a few hundreds of micrometres in size. Additionally, löllingite and gersdorffite occur as small, commonly zoned crystals in galena and tetrahedrite aggregates.

\section{GALENA PbS}

Galena is the main ore mineral of the baryte-sulphide ore. Galena forms aggregates up to several centimetres across, series of parallel veinlets in baryte veins, as well as breccia infill- ings cementing baryte and quartz fragments. Galena aggregates are intergrown with sphalerite, Ag-tetrahedrite and chalcopyrite (Fig. 2A, C, G). Some aggregates include abundant inclusions of silver-bearing mineral phases [members of the freibergite series: "freibergite-(Fe)" and "freibergite-(Zn)", bournonite, pyrargyrite and polybasite; Fig. 2E]. Commonly, galena is replaced by various secondary minerals especially cerussite, less so covellite. Galena is chemically homogeneous and has a low content of trace elements.

\section{SPHALERITE ZnS}

Sphalerite crystals are irregularly distributed within baryte-quartz veins and are overgrown by galena and chalcopyrite (Fig. 2A). Sphalerite forms two generations where sphalerite II usually grows over primary massive aggregates of sphalerite I (Fig. 2G). The sphalerite has a generally low Fe content (up to $0.01 \mathrm{apfu}$ ) and is comparatively Cd-rich (up to $0.04 \mathrm{apfu}$ ) (Appendix $1^{*}$ ). Intense brown internal reflections are observed, which are probably related to a lattice substitution of Cd for $\mathrm{Zn}$. The highest Cd contents (0.03-0.04 apfu) are observed in the second generation of sphalerite. The Hg concentration in sphalerite reaches up to $0.01 \mathrm{apfu}$, Cu reaches up to 0.01 apfu. The generalized empirical formula is: $\left(\mathrm{Zn}_{0.95-0.99} \mathrm{Cd}_{0.00-0.04} \mathrm{Fe}_{0.00-0.01}\right)_{\Sigma=1} \mathrm{~S}_{0.99-1.01}$.

\section{TETRAHEDRITE GROUP MINERALS}

At Boguszów, there are four generations of TGM defined according to textural characteristics and silver content (Fig. 3A). The nomenclature follows the new classification of TGM (Biagioni et al., 2020a):

1 - low-Ag tetrahedrite-(Zn) (Ag: 0.22-0.6 apfu),

2 - Ag-enriched tetrahedrite-( $\mathrm{Zn})$ and Ag-enriched tetrahedrite-(Fe) (Ag: 0.71-1.45 apfu),

3 - members of the freibergite series: "freibergite-(Fe)" and "freibergite-(Zn)" (Ag: 3.21-3.48 apfu),

$4-$ member of the freibergite series: "freibergite-(Fe)" (Ag: 5.32-5.78 apfu).

\section{LOW-Ag TETRAHEDRITE-(Zn)}

Low-Ag tetrahedrite-( $\mathrm{Zn})$ is observed as idiomorphic crystals up to $5 \mathrm{~mm}$ in size without any inclusions and without other sulphides association (Fig. 2B). Representative analyses of the tetrahedrite-(Zn) are shown in Appendix 2. The low-Ag tetrahedrite-( $\mathrm{Zn})$ is characterized by small variation in $\mathrm{Cu}$ and Ag concentrations. Individual results mostly vary in As content (from 0.57 to 1.74 apfu; Fig. 3B). This generation of TGM is the zinc member of the tetrahedrite series (Fig. 4B). A generalized formula for low-Ag tetrahedrite-( $\mathrm{Zn})$ based on 16 cations is: $\left(\mathrm{Cu}_{9.37-9.80} \mathrm{Ag}_{0.22-0.60} \mathrm{Zn}_{1.16-1.72} \mathrm{Fe}_{0.22-0.77} \mathrm{Hg}_{0.02-0.05}\right)_{\Sigma=11.95-12.01}\left(\mathrm{Sb}_{2.24}\right.$ $\left.{ }_{-3.47} \mathrm{As}_{0.57-1.74} \mathrm{Bi}_{0.01}\right)_{\Sigma=3.99-4.05} \mathrm{~S}_{13.02-13.11}$. Similar low-Ag tetrahedrite with 3 wt.\% of Ag was reported by Migaszewski (1972) from veinlets criss-crossing altered volcanic rock.

$$
\begin{gathered}
\text { Ag-ENRICHED TETRAHEDRITE-(Zn) + Ag-ENRICHED } \\
\text { TETRAHEDRITE-(Fe) }
\end{gathered}
$$

Ag-enriched tetrahedrite-(Zn) and Ag-enriched tetrahedrite-(Fe) are intergrown with galena and chalcopyrite, as well as 

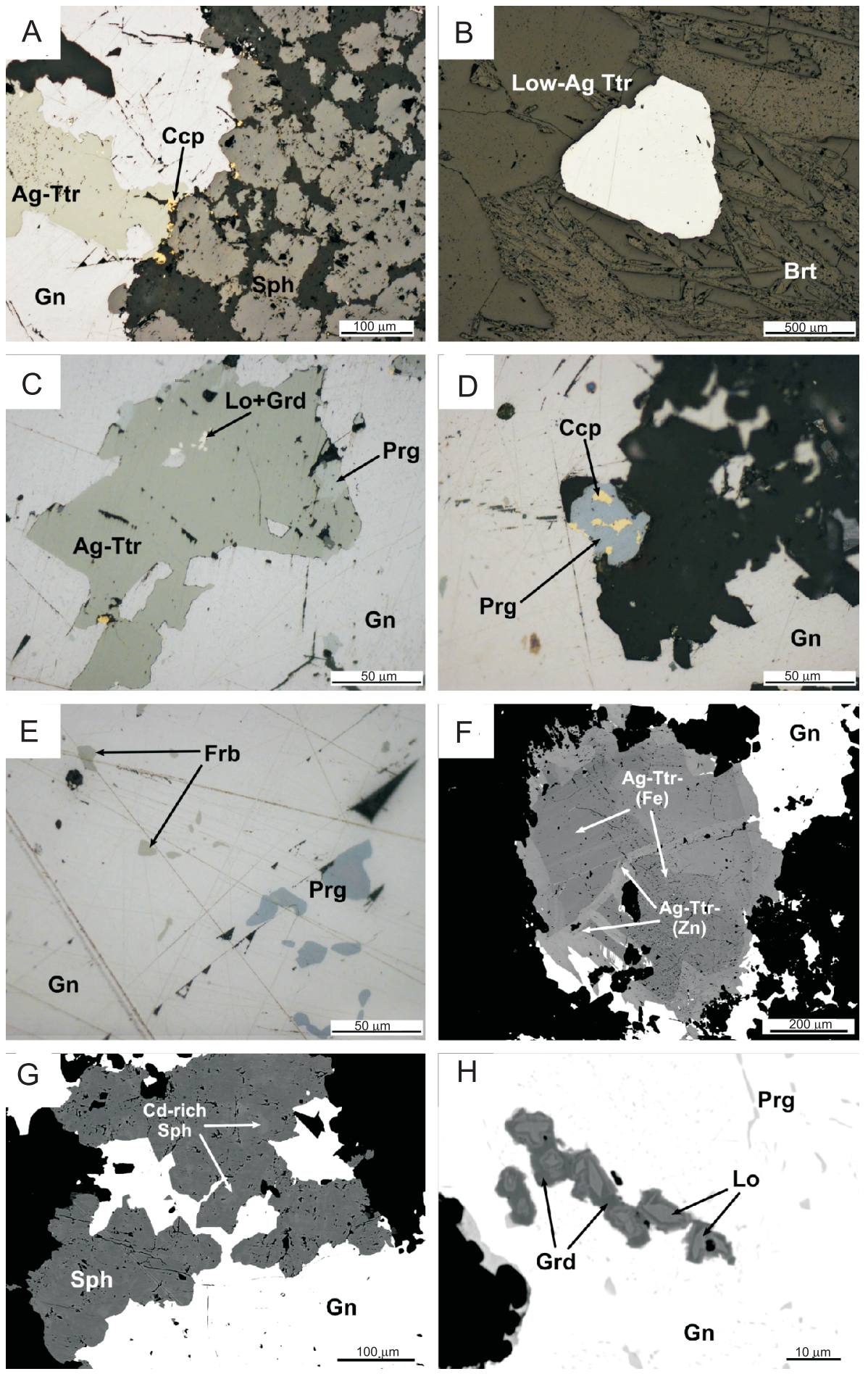

Fig. 2. Optical (reflected light, 1P) (A-E) and BSE images (F-H) illustrating the main features of mineral assemblages

A - galena - Ag-enriched tetrahedrite - sphalerite aggregate with chalcopyrite; B - single idiomorphic low-Ag tetrahedrite-(Zn) crystal in baryte; C - galena - Ag-enriched tetrahedrite aggregate with pyrargyrite and löllingite-gersdorffite inclusions; D - pyrargyrite - chalcopyrite aggregate at the edge of galena; $\mathbf{E}$ - linear inclusions of pyrargyrite and members of the freibergite series in galena; $\mathbf{F}$ - zonation in Ag-enriched tetrahedrite crystal reflecting iron and zinc abundances; $\mathbf{G}$ - galena-sphalerite aggregate with some secondary Cd-enriched zones in sphalerite; $\mathbf{H}$ - löllingite-gersdorffite inclusions in galena; Ag-Ttr - Ag-enriched tetrahedrite; Brt - baryte; Ccp - chalcopyrite; Frb - members of the freibergite series; Gn - galena; Grd - gersdorffite; Lo löllingite; Low-Ag Ttr - low-Ag tetrahedrite-(Zn); Prg - pyrargyrite; Sph - sphalerite 

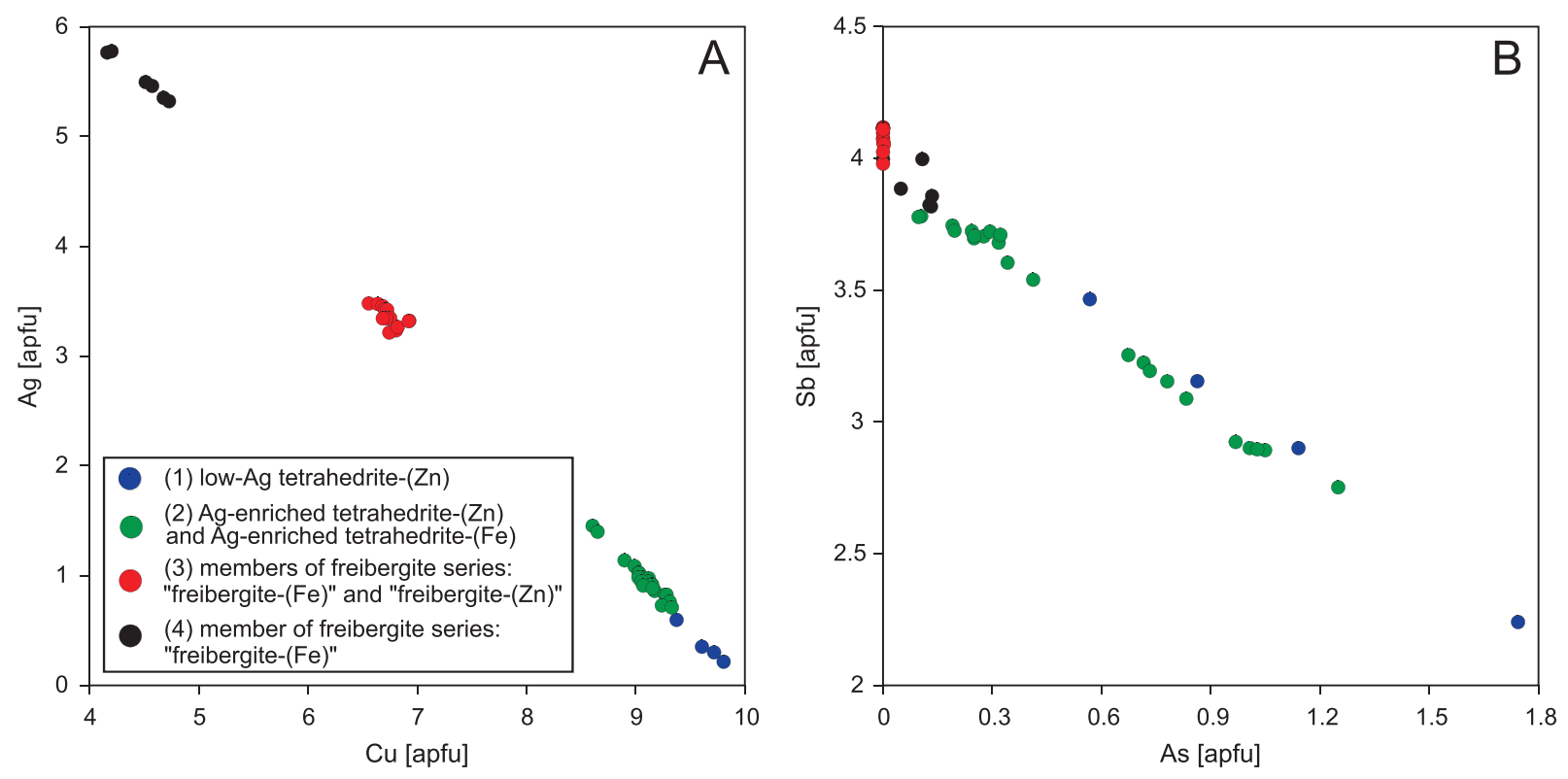

Fig. 3. Compositional relationships in the tetrahedrite series from Boguszów

A - diagram of Ag-Cu substitution in TGM; $\mathbf{B}$ - diagram of Sb-As substitution in TGM

occuring as irregular aggregates up to $0.5 \mathrm{~mm}$ across (Fig. 2A, C, $\mathrm{H})$. Some aggregates are enriched in tiny chalcopyrite and löllingite inclusions up to $20 \mu \mathrm{m}$ in size (Fig. 2C). Results of chemical analysis of this generation of TGM are shown in Appendix 2. As in the previous generation, a similar trend of the As-Sb substitution is observed (Fig. 3B). Microprobe analyses indicate a wide range of $\mathrm{Zn}-\mathrm{Fe}$ substitution and a dominance of the zinc member of the tetrahedrite series (Fig. 4B). Element ranges in the $\mathrm{D}$ position in the TGM are $\mathrm{Fe}-0.26-1.15 \mathrm{apfu}$, and $\mathrm{Zn}-0.8-1.79$ apfu respectively. A generalized formula can be expressed as: $\left(\mathrm{Cu}_{8.61-9.33} \mathrm{Ag}_{0.71-1.45} \mathrm{Zn}_{0.80-1.79} \mathrm{Fe}_{0.26-1.15} \mathrm{Hg}_{0.00-0.05}\right)_{\Sigma=11.96-12.08}\left(\mathrm{Sb}_{2.75}\right.$ $\left.-3.78 \mathrm{As}_{0.10-1.25} \mathrm{Bi}_{0.01-0.09}\right)_{\Sigma=3.92-4.04} \mathrm{~S}_{13.02-13.42}$.

MEMBERS OF THE FREIBERGITE SERIES:
"FREIBERGITE-(Fe)" AND "FREIBERGITE-(Zn)"

Members of the freibergite series, "freibergite-(Fe)" and "freibergite-(Zn)", occur as elongated inclusions up to $100 \mu \mathrm{m}$ long along galena cleavage planes, as well as tiny irregular inclusions (Fig. 2E). The compositional variation of this tetrahedrite generation is shown in Appendix 2. This generation tends to be As-poor, As - up to 0.002 apfu. Consequently, Sb content is relatively uniform and ranges between 3.98-4.12 apfu. Most of the freibergites are "freibergite-(Zn)", which is currently not a defined member of the freibergite series (Biagioni et al., 2020a): Zn concentration ranges from 0.11 to $1.17 \mathrm{apfu}$, Fe content is generally lower and reaches up to 0.98 apfu (Fig. 4B-D). Moreover, some of the EPMA analyses show relatively high mercury contents of up to 0.75 apfu. The highest $\mathrm{Hg}$ content was measured in freibergite-(Fe), where Fe contents exceed $\mathrm{Zn}, \mathrm{Hg}$ decreases with increasing $\mathrm{Zn}$ content. Additionally, $\mathrm{Hg}$-enriched freibergite has the lowest silver content in this generation of freibergites (3.26-3.32 apfu). Comparative readings of $\mathrm{Zn}$ versus $\mathrm{Fe}+\mathrm{Hg}$ (Fig. 4B) and $\mathrm{Zn}$ versus $\mathrm{Fe}+\mathrm{Hg}+(\mathrm{Cu}+\mathrm{Ag}-6)$ cross-plots (Fig. $4 \mathrm{C})$ show that copper in position $\mathrm{C}$ is common in this TGM generation. The generalized formula for "freibergite-(Fe)" and "freibergite-(Zn)" is: $\left(\mathrm{Cu}_{6.56-6.93} \mathrm{Ag}_{3.21-3.48} \mathrm{Zn}_{0.11-1.17} \mathrm{Fe}_{0.56-0.98} \mathrm{Hg}_{0.01-0.75}\right)_{\Sigma=11.87-12.01}\left(\mathrm{Sb}_{3.98}\right.$

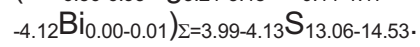

MEMBER OF THE FREIBERGITE SERIES: "FREIBERGITE-(Fe)"

One crystal of "freibergite-(Fe)" was found in the samples. This member of the freibergite-(Fe) series has grown over the pyrargyrite and formed a $20 \mu \mathrm{m}$ irregular aggregate. It is characterized by homogeneous chemical composition; the results are shown in Appendix 2. A generalized formula based on 16 cations can be expressed as: $\left(\mathrm{Ag}_{5.32-5.78} \mathrm{Cu}_{4.16-4.73} \mathrm{Fe}_{1.86-1.99} \mathrm{Zn}_{0.02-0.15} \mathrm{Hg}_{0.00-0.02}\right)_{\Sigma=11.89-12.06}\left(\mathrm{Sb}_{3.82}\right.$ $\left.-4.00 \mathrm{As}_{0.00-0.13} \mathrm{Bi}_{0.01}\right)_{\Sigma=3.94-4.11} \mathrm{~S}_{12.25-12.65 \text {. }}$

\section{PYRARGYRITE $\mathrm{Ag}_{3} \mathrm{SbS}_{3}$}

The pyrargyrite investigated mostly occurs as inclusions up to $50 \mu \mathrm{m}$ across in galena (Fig. 2E). Pyrargyrite intergrowths with chalcopyrite (up to $100 \mu \mathrm{m}$ across) are also present (Fig. 2D). They are characterized by uniform chemical composition (Appendix 1). Generally, pyrargyrite is practically arsenic-free. Only isolated pyrargyrite grains are characterized by notably higher As concentrations ( 2 wt.\%). A generalized pyrargyrite formula based on 4 cations is: $\left(\mathrm{Ag}_{2.97-3.01} \mathrm{Cu}_{0.00-0.02}\right)_{\Sigma=2.98-3.01}\left(\mathrm{Sb}_{0.82-1.02} \mathrm{As}_{0.00-0.17}\right)_{\Sigma=0.99-1.02} \mathrm{~S}_{3.09-3.14}$.

$$
\text { POLYBASITE Cu(Ag, Cu) })_{6} \mathrm{Ag}_{9} \mathrm{Sb}_{2} \mathrm{~S}_{11}
$$

This mineral occurs as rounded inclusions up to $20 \mu \mathrm{m}$ across randomly distributed in galena crystals. Polybasite is characterized by a homogeneous chemical composition (Appendix 1). The inclusions investigated have more $\mathrm{Cu}$, as well as less Sb and S than ideal, stoichiometric polybasite. The generalized empirical polybasite formula based on 18 cations is: $\mathrm{Cu}\left(\mathrm{Ag}_{5.68-5.80} \mathrm{Cu}_{0.20-0.32}\right)_{\Sigma=6} \mathrm{Ag}_{9.08-9.23} \mathrm{Sb}_{1.76-1.90} \mathrm{~S}_{10.15-10.62}$.

$$
\text { BOURNONITE } \mathrm{PbCuSbS}_{3}
$$

This mineral is a minor phase and occurs as inclusions related to the cleavage planes in galena crystals. Most of the bournonite inclusions in samples from Boguszów are too small 

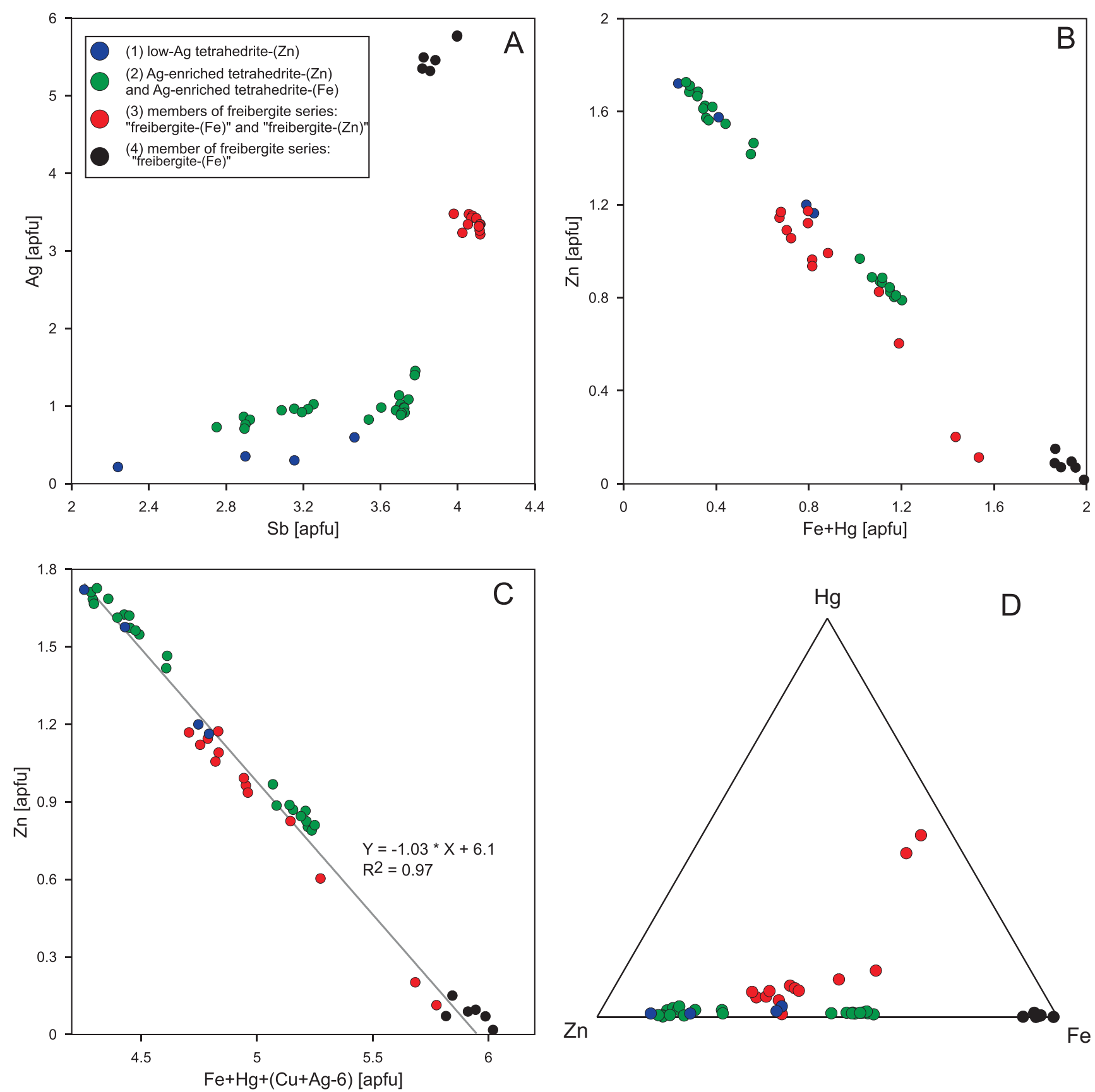

Fig. 4. Compositional relationships in the tetrahedrite series from Boguszów

A - diagram of Ag versus Sb in TGM; B - diagram of $\mathrm{Zn}$ vs Fe+Hg substitution in TGM; C - variation of Zn (apfu) as a function of $\mathrm{Fe}+\mathrm{Hg}+(\mathrm{Cu}+\mathrm{Ag}-6)(\mathrm{apfu}) ; \mathbf{D}-$ ternary diagram, $\mathrm{Zn}$ versus $\mathrm{Fe}$ versus $\mathrm{Hg}(\mathrm{apfu})$ of the TGM

to be quantitatively analysed by EPMA due to their fine grain size (up to 1-3 $\mu \mathrm{m}$ ). It was possible to measure only some inclusions, the chemical composition is close to the ideal formula without any significant substitutions.

\section{LÖLLINGITE FeAs}

Löllingite occurs as idiomorphic crystals up to $10 \mu \mathrm{m}$ in size within galena and Ag-enriched tetrahedrite aggregates (Fig. 2C, H). A summary of the analytical results available for löllingite are shown in Appendix 1. In comparison with stoichiometric löllingite, the löllingite from Boguszów is Fe-depleted (0.67-0.91 apfu), besides Co (0.03-0.24 apfu) and Ni (up to $0.16 \mathrm{apfu}$ ) enrichment.

\section{GERSDORFFITE NiAsS}

Gersdorffite appears as thin rims (up to several $\mu \mathrm{m}$ thick) around löllingite crystals (Fig. 2C, H). The compositional variation of gersdorffite is shown in Appendix 1. Gersdorffite is 
generally enriched in Co (0.11-0.37 apfu), less in Fe (0.07-0.22 apfu). Common substitutions between cobalt, nickel, and iron are observed in the gersdorffite from the Boguszów. The generalized empirical gersdorffite formula is: $\left(\mathrm{Ni}_{0.53-0.81} \mathrm{Co}_{0.11-0.37} \mathrm{Fe}_{0.07-0.22}\right)_{\Sigma=1} \mathrm{As}_{1.03-1.14} \mathrm{~S}_{0.90-0.98}$. Transition zones between löllingite crystals and gersdorffite rims are observed, but are too small to be measured by EPMA.

\section{DISCUSSION}

\section{SILVER MINERALIZATION IN SUDETES AND BOHEMIAN MASSIF}

The Sudetes in Poland include $\sim 30$ recorded baryte veins (Paulo, 1994), the highest rate of occurrence being observed in the Sowie Mountains and the Intra-Sudetic Depression. Polymetallic $\mathrm{Pb}-\mathrm{Zn}-\mathrm{Ag}$ mineralization is associated with a large part of these veins. Mining, which goes back to medieval times, was focused towards the silver-rich ores. However, previous reports of silver minerals and Ag-rich TGM in the old literature do not contain reliable chemical data, including from Boguszów (Traube, 1888; Migaszewski, 1972) and Dziećmorowice (Petrascheck, 1933). Direct comparison is possible only with hydrothermal mineralization from Zagórze Ślaskie (Piestrzyński and Kowalik, 2015) and Bystrzyca Górna (BG) (Pršek et al., 2019), which are located within the Sowie Mountains. For example, polymetallic mineralization in the baryte veins from Zagórze Ślaskie is characterized by a higher abundance of Cu minerals. More mineralogical similarities with the mineralization studied can be found in polymetallic Ag-Sb$-\mathrm{Pb}-(\mathrm{Cd})$ mineralization related to baryte veins at BG. Pršek et al. (2019) reported the presence of e.g. silver-enriched TGM, $\mathrm{Ag}-\mathrm{Sb}-\mathrm{S}, \mathrm{Ag}-\mathrm{Pb}-\mathrm{S}$ and $\mathrm{Pb}-\mathrm{Sb}$ sulphosalts (Table 1). In contrast to textures of Ag mineralization from Boguszów (elongated inclusions in galena), at BG silver mineralization forms veinlets and disseminations in a fine-grained dark baryte-quartz matrix. In contrast to the Boguszów hydrothermal system, in BG arsenic is absent from the entire paragenetic sequence, the mineralization being extremely Sb-rich. According to Pršek et al. (2019) a smoother transition of $\mathrm{Cu}^{+}-\mathrm{Ag}^{+}$substitution in TGM was recognized at BG. Chemical zonation regarding the distribution of $\mathrm{Ag}$ abundances is observed, freibergite-(Fe) rims around lower-Ag TGM being common at this locality. At Boguszów four particular TGM generations have been distinguished (Fig. 3A). As Pršek et al. (2019) state about BG, the former tetrahedrite (related to the early stage base metal mineralization) was dissolved by younger Ag-rich fluids, which are responsible for unusual Ag-Sb-Pb-(Cd) mineralization. In comparison to the mineralization from BG, textural features in ores from Boguszów indicate an increase in Ag-rich phases [freibergite-(Fe), pyrargyrite and polybasite] during the younger epithermal stages. As previously mentioned, in the past, more silver mines were active within the Bohemian Massif (Table 2). Silver was recovered mainly from Ag-rich TGM and Ag-Sb sulphosalts, which occur in baryte quartz \pm carbonate veins. In general, Ag-bearing tetrahedrite or freibergite is one of the most important sources of silver in these silver-bearing mining districts in the Czech Republic and Poland. The accompanying silver minerals are variable and the presence of individual minerals depends on various oreforming conditions as well as the local geochemical source of mineralization.

\section{MERCURY IN TETRAHEDRITE} GROUP MINERALS

The presence of mercury in the TGM from Boguszów is restricted to few samples. The highest enrichment is observed in member of the "freibergite-(Fe)" series, which is Sb-rich and $\mathrm{Zn}$-depleted - similarly to the hybrid massive sulphide-epithermal Eskay Creek deposit in Canada (Grammatikopoulos et al., 2005). Hg-Ag tetrahedrite from Eskay Creek (Hg: 0.12-1.54 apfu; Ag: 1.11-3.66 apfu - based on 16 cations) is associated with sphalerite-tetrahedrite, cinnabar, galena, stibnite and $\mathrm{Pb}-\mathrm{Sb}$ sulphosalts. Another occurrence of $\mathrm{Hg}$-Ag tetrahedrite from Chiprovtsi Ag-Pb (Bulgaria) was reported by Atanasov (1975). Ag-Hg rich tetrahedrite (Hg: 1.82-1.86 apfu; $\mathrm{Ag}$ : 2.88-3.13 apfu - based on 16 cations) is associated with the pyrite-cinnabar stage and forms rims around cinnabar aggregates. Mercury-dominant tetrahedrite group minerals (Biagioni et al., 2020a) are common in the mineralization rich in mercury and have been reported from many localities (e.g., Mozgova et al., 1979; Arlt and Diamond, 1998; Foit and Ulbricht, 2001; Karanović et al., 2003; Krismer et al., 2011; Velebil, 2014; Števko et al., 2015; Biagioni et al., 2020b). Tetrahedrite enriched in $\mathrm{Hg}$ is generally Ag-free or Ag-low and it is associated with $\mathrm{Cu}, \mathrm{Hg}, \mathrm{As}, \mathrm{Sb}, \mathrm{Bi}$ minerals in quartz or quartz-carbonate-baryte veins as reported worldwide. Examples of the chemical composition of Ag- and Hg-rich TGM are shown in the ternary $\mathrm{Ag}$ versus $\mathrm{Zn}$ and $\mathrm{Zn}$ versus Fe versus $\mathrm{Hg}$ diagrams (Fig. 5). The most Ag-enriched Hg-rich TGM tend to be $\mathrm{Zn}$-poor.

\section{Ni-Co ASSOCIATION}

Nickel and cobalt minerals are present in various hydrothermal occurrences and deposits. Especially characteristic is the "five-element vein type" mineralization ("Ag-Co-Ni-As-Bi type") (Kissin, 1992; Markl et al., 2016; Scharrer et al., 2019). Ni-Co enrichment in hydrothermal mineralization may also be related to leaching of these elements by hydrothermal fluids from the surrounding ultramafic rocks (Dolníček et al., 2019a). In the Boguszów baryte deposit the $\mathrm{Ni}$-Co assemblage is represented by tiny aggregates of Co-enriched löllingite and gersdorffite. Additionally, small isometric inclusions of cobaltite in tetrahedrite up to $15 \mu \mathrm{m}$ in size were reported by Migaszewski (1972). Metals in this assemblage were probably sourced from the ultramafic basement of the Intra-Sudetic Ophiolite, as was proposed for hydrothermal veins in the Moravo-Silesian Culm from the Řepová - ultramafic Zábřeh Crystalline Complex, where a $\mathrm{Ni}-\mathrm{Co}$ assemblage is associated with base metal $+\mathrm{Ag}-\mathrm{Hg}-\mathrm{Au}$ mineralization (Dolníček et al., 2019a).

\section{CONCLUSIONS}

1. Silver in the Boguszów baryte deposit occurs in the form of its minerals: Ag-Sb sulphosalts (pyrargyrite, polybasite) and tetrahedrite group minerals (TGM). The composition of these minerals, which form elongated inclusions in galena aggregates, was determined using an electron microprobe.

2. Other ore minerals found are galena, sphalerite, pyrite chalcopyrite, bournonite, löllingite and gersdorffite.

3. Four generations of the TGM were distinguished according to textural characteristics and Ag concentrations:

1 - low-Ag tetrahedrite-(Zn) (Ag: 0.22-0.6 apfu), 


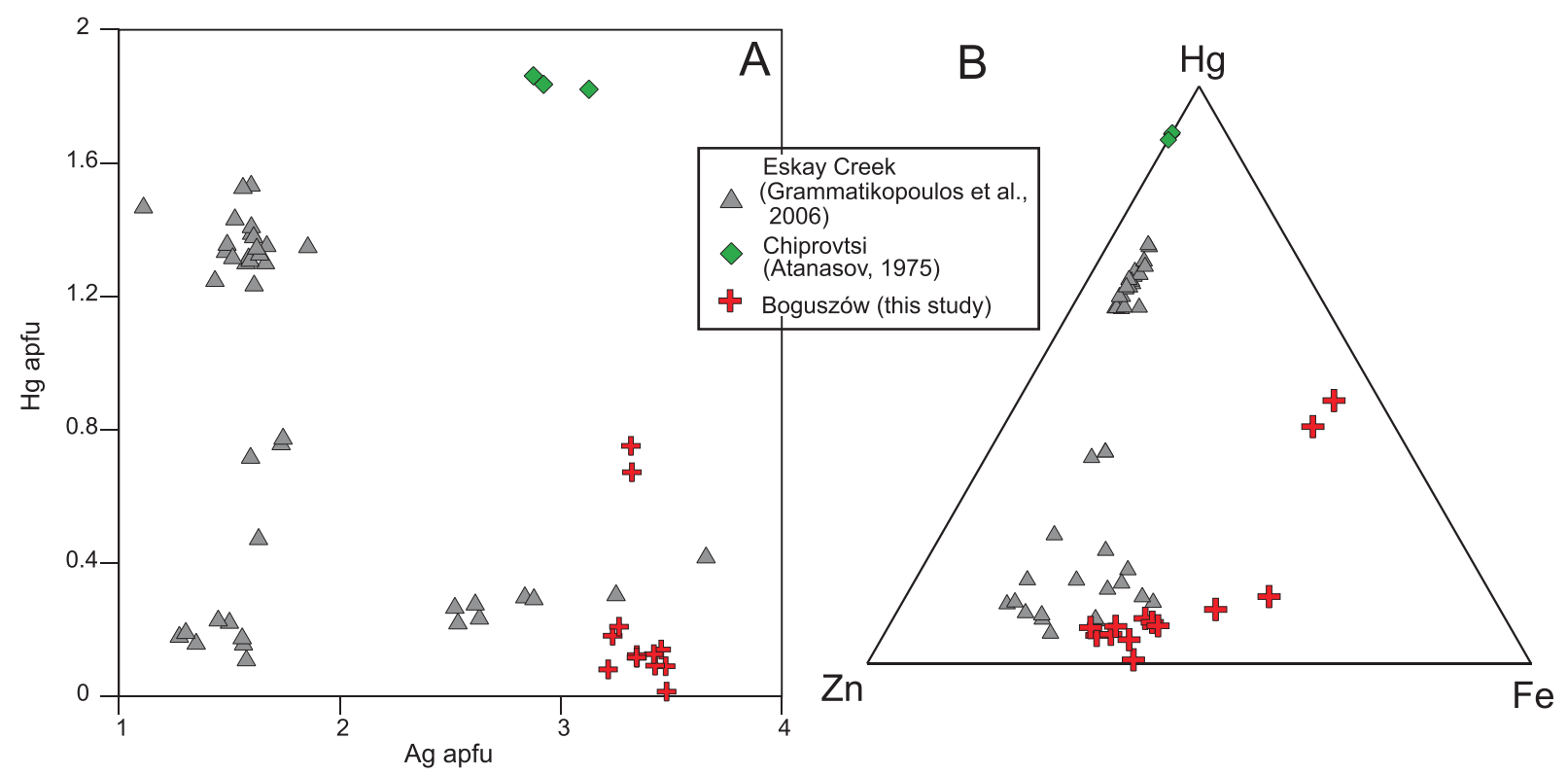

Fig. 5. Compositional relationships in the Ag- and Hg-rich TGM from Boguszów ( $n=13)$, Eskay Creek $(n=40)$ (Grammatikopoulos et al., 2005) and Chiprovtsi $(\mathbf{n}=3$ ) (Atanasov, 1975); $\mathbf{n}$ - number of analyses

A - diagram of Ag versus $\mathrm{Hg}$ in TGM; B - ternary diagram Zn versus Fe versus $\mathrm{Hg}$ (apfu) in the TGM

2 - Ag-enriched tetrahedrite-(Zn) and Ag-enriched tetrahedrite-(Fe) (Ag: 0.71-1.45 apfu),

3 - members of the freibergite series: "freibergite-(Fe)" and "freibergite-(Zn)" (Ag: 3.21-3.48 apfu),

4 - member of the "freibergite-(Fe)" series (Ag: 5.32-5.78 apfu).

4. Similar Ag mineralization occurrences related to $\mathrm{Ag}-\mathrm{Pb}-$ -Sb minerals are known from several localities in the Sudetes and the Bohemian Massif.

5. The Boguszów baryte deposit is one of the few localities known in the world with Hg-rich members of freibergite series.
6. The presence of cobalt-enriched löllingite and gersdorffite may indicate leaching of $\mathrm{Ni}$ and $\mathrm{Co}$ by hydrothermal fluids from the ultramafic basement.

Acknowledgements. We are grateful to G. Kozub-Budzyń from the Laboratory of Critical Elements at AGH-UST for help during EPMA data collection. We are also grateful to the reviewers, J. Sejkora and S. Mikulski, whose comments helped us to improve the manuscript. This work is part of the research program financed by the AGH University of Science and Technology statutory grant No. 11.11.140.320.

\section{REFERENCES}

Arlt, T., Diamond, L.W., 1998. Composition of tetrahedrite-tennantite and schwazite in the Schwaz silver mines, North Tyrol, Austria. Mineralogical Magazine, 62: 801-820.

Atanasov, V.A., 1975. Argentian mercurian tetrahedrite, a new variety, from the Chiprovtsi ore deposit, Western Stara-Planina mountains, Bulgaria. Mineralogical Magazine, 40: 233-237.

Awdankiewicz, M., Kryza, R., 2010. The Chełmiec subvolvanic intrusion (Intra-Sudetic Basin, SW Poland): preliminary SHRIMP zircon age. Mineralogia - Special Papers, 37: 69.

Banaś, M., Mochnacka, K., 1986. The two uranium deposits in the Polish part of the Sudety Mountains. In: Vein Type Uranium Deposits (ed. H. Fuchs): 335-357. International Atomic Energy Agency, Wien.

Bestemianova, K.V., Grinev, O.M., 2017. Barite-polymetallic mineralization of Zmeinogorsk ore district and some genetic aspects of its formation. In: IOP Conference Series: Earth and Environmental Science, 110:1-7. IOP Publishing.

Biagioni, C., George, L.L., Cook, N.J., Makovicky, E., Moëlo, Y., Pasero, M., Sejkora, J., Stanley, C.J., Welch, M.D., Bosi, F., 2020a. The tetrahedrite group: Nomenclature and classification. American Mineralogist, 105: 109-122.
Biagioni, C., Sejkora, J., Musetti, S., Velebil, D., Pasero, M., 2020b. Tetrahedrite- $(\mathrm{Hg})$, a new "old" member of the tetrahedrite group. Mineralogical Magazine, 84: 584-592.

Cheilletz, A., Levresse, G., Gasquet, D., Azizi-Samir, M., Zyadi, R., Archibald, D.A, Farrar, E., 2002. The giant Imiter silver deposit: Neoproterozoic epithermal mineralization in the Anti-Atlas, Morocco. Mineralium Deposita, 37: 772-781.

Dolníček, Z., Nepejchal, M., Ulmanová, J., 2019a. Řepová near Mohelnice - mineralogically the most diverse ore vein mineralization in the Moravo-Silesian Culm (in Czech with English summary). Bulletin Mineralogie Petrologie, 27: 109-135.

Dolníček, Z., Skácel, J., Nepejchal, M., 2019b. New findings on silver-rich vein mineralization of the $\mathrm{Zn}-\mathrm{Pb}$ deposit Horní Město (Vrbno Group, Silesicum) (in Czech with English summary). Bulletin Mineralogie Petrologie, 27: 279-289.

Dziedzic, K., 1971. Sedimentation and paleogeography of the Upper Carboniferous deposits in the Intrasudetic depression. Geologia Sudetica, 5: 65-75.

Foit Jr, F.F., Ulbricht, M.E., 2001. Compositional variation in mercurian tetrahedrite-tennantite from the epithermal deposits 
of the Steens and Pueblo Mountains, Harney County, Oregon. Canadian Mineralogist, 39: 819-830.

Gemmell, J.B., Zantop, H., Birnie, R.W., 1989. Silver sulfosalts of the Santo Nino vein, Fresnillo District, Zacatecas, Mexico. Canadian Mineralogist, 27: 401-418.

Gołębiowska, B., Pieczka, A., Parafiniuk, J., 2012. Substitution of $\mathrm{Bi}$ for $\mathrm{Sb}$ and $\mathrm{As}$ in minerals of the tetrahedrite series from Rędziny, Lower Silesia, southwestern Poland. Canadian Mineralogist, 50: 267-279.

Grammatikopoulos, O., Roth, T., Valeyev, O., 2005. Compositional variation in $\mathrm{Hg}-\mathrm{Ag}$-rich tetrahedrite from the polymetallic Eskay Creek deposit, British Columbia, Canada. Neues Jahrbuch für Mineralogie Abhandlungen, 181: 281-292.

Grocholski, A., 1965. The volcanic rocks in the Walbrzych Basin in the light of structural studies (in Polish with English summary). Biuletyn Instytutu Geologicznego, 191: 5-67.

Grossou-Valta, M., Adam, K., Constantinides, D.C., Prevosteau, J.M., Dimou, E., 1990. Mineralogy of and potential beneficiation process for the Molai complex sulphide orebody, Greece. In: Sulphide Deposits - their Origin and Processing (eds. P.M.J. Gray, G.J. Bowyer, J.F. Castle, D.J. Vaughan and N.A. Warner): 119-133. The Institution of Mining and Metallurgy, Dordrecht.

Gruszczyk, H., 1952. Złoża barytu w Boguszowie I Jabłowie na Dolnym Śląsku (in Polish). Wyd. Geol., Warszawa.

Gruszczyk, H., Paulo, A., Smolarska, J., 1970. The present knowledge on the baryte deposit at Boguszów, Lower Silesia (in Polish with English summary). Prace Instytutu Geologicznego, 59: $69-84$.

Höller, W., Gandhi, S.M., 1995. Silver bearing sulfosalts from the metamorphosed Rampura Agucha Zn-Pb-(Ag) deposit, Rajasthhan, India. Canadian Mineralogist, 33: 1047-1057.

Hrazdil, V., Škrdla, P., Houzar, S., Vokáč, M., 2012. Historic mining of silver ore in Komárovice near Jihlava, west Moravia (in Czech with English summary). Acta rerum naturalium, 12: 137-144.

Karanović, L., Cvetković, L., Poleti, D., Balić-Žunić, T., Makovicky, E., 2003. Structural and optical properties of schwazite from Dragodol (Serbia). Neues Jahrbuch für Mineralogie Monatshefte, (11): 503-520

Kissin, S.A., 1992. Five-element (Ni-Co-As-Ag-Bi) veins. Geoscience Canada, 19: 113-124.

Kołodziejczyk, J., Pršek, J., Asllani, B., Maliqi, F., 2016. The paragenesis of silver minerals in the $\mathrm{Pb}-\mathrm{Zn}$ Stan Terg deposit, Kosovo: an example of precious metal epithermal mineralization. Geology, Geophysics and Environment, 42: 19-29.

Kozub-Budzyń, G.A., Piestrzyński, A., 2018. The first occurrence of cupropearceite in the Kupferschiefer deposit, Lubin mine, SW Poland. Geological Quarterly, 62 (2): 319-326.

Krismer, M., Vavtar, F., Tropper, P., Kaindl, R., Sartory, B., 2011. The chemical composition of tetrahedrite-tennantite ores from the prehistoric and historic Schwaz and Brixlegg mining areas (North Tyrol, Austria). European Journal of Mineralogy, 23: 925-936.

Kurowski, L., 1998. Fluvial sedimentology of the Biały Kamień Formation (Upper Carboniferous, Sudetes, Poland). Geologia Sudetica, 31: 69-77.

Lis, J., Sylwestrzak, H., 1986. Minerały Dolnego Śląska (in Polish). Wyd. Geol., Warszawa

Manecki, A., 1965. Mineralogical and petrographical study of the polymetallic veins from the area of Wojcieszów (Lower Silesia) (in Polish with English summary). Prace Mineralogiczne, 2: $1-71$.

Markl, G., Burisch, M., Neumann, U., 2016. Natural fracking and the genesis of five-element veins. Mineralium Deposita, 51: 703-712.

Mastalerz, K., 1996. Sedimentation of the Zacler Formation (Westphalian) in the Walbrzych basin, SW Poland. Prace Geologiczno-Mineralogiczne, 52: 21-93.

Mastalerz, K., Mastalerz, M., 2000. Volcanic and post-volcanic hydrothermal activity in the Intrasudetic Basin, SW Poland: impli- cations for mineralization. In: Organic Matter and Mineralisation: Thermal Alteration, Hydrocarbon Generation and Role in Metallogenesis (eds. M. Glikson and M. Mastalerz): 185-202. Springer, Dordrecht.

Migaszewski, Z., 1972. Mineralizacja kruszcowa w złożu barytu w Boguszowie (in Polish). Rudy i Metale Nieżelazne, 9: 425-428.

Mikulski, S., 2005. Geological, mineralogical and geochemical characteristics of the Radzimowice Au-As-Cu deposit from the Kaczawa Mts. (Western Sudetes, Poland) - an example of the transition of porphyry and epithermal style. Mineralium Deposita, 39: 904-920.

Mikulski, S., 2010. The characteristic and genesis of the gold-bearing arsenic polymetallic mineralization in the Czarnów deposit (Western Sudetes) (in Polish with English summary). Biuletyn Państwowego Instytutu Geologicznego, 439: 303-320.

Mochnacka, K., Banaś, M., 2000. Occurrence and genetic relationships of uranium and thorium mineralization in the Karkonosze Izera Block (the Sudety Mts, SW Poland). Annales Societatis Geologorum Poloniae, 70: 137-150.

Mozgova, N.N., Tsepin, A.l., Ozerova, N.N., Bortnikov, N.S., Tronieva, N.V., 1979. Mercuriferous grey copper ores (in Russian). Zapiski Vsesoyuznogo Mineralogicheskogo Obshchestva, 108: 437-452.

Paulo, A., 1994. Geology of barite Veins in the Polish Sudetes. In: Metallogeny of Collisional Orogens (eds. R. Seltman, H. Kämpf and P. Möller): 383-390. Czech Geological Survey, Prague.

Paulo, A., Salamon, W., 1974a. A note on freibergite, pyrargyrite and bournonite from Grudno, Lower Silesia (in Polish with English summary). Mineralogia Polonica, 5: 83-86.

Paulo, A., Salamon, W., 1974b. Contribution to the knowledge of a polymetallic deposit at Stara Góra (in Polish with English summary). Geological Quarterly, 18 (2): 266-278.

Pažout, R., Šrein, V., Korbelová, Z., 2017. An unusual $\mathrm{Ni}-\mathrm{Sb}$-Ag-Au association of ullmannite, allargentum, Au-rich silver and Au-bearing dyscrasite from Oselské pásmo" silver" Lode of Kutná Hora Pb-Zn-Ag ore district (Czech Republic). Journal of Geosciences, 62: 247-252.

Pažout, R., Sejkora, J., Šrein, V., 2019. Ag-Pb-Sb sulfosalts and Se-rich mineralization of Anthony of Padua Mine near Poličany - model example of the mineralization of Silver Lodes in the historic Kutná Hora Ag-Pb Ore District, Czech Republic. Minerals, 9: 430 .

Petrascheck, W.E., 1933. Die Erzlagerstätten des Schlesischen Gebirges. Archiv Lagerstättenforschung, Germany.

Piestrzyński, A., Kowalik, K., 2015. Argentopentlandite from barite vein in Zagórze Ślaskie, Lower Silesia, a first occurrence in Poland. Mineralogia, 45: 13-25.

Piestrzyński, A., Mochnacka, K., 2003. Discussion on the sulphide mineralization related to the tin-bearing zones of the Kamienica schists belt (Western Sudety Mountains, SW Poland) (in Polish with English summary). In: Sudety Zachodnie - od wendu do czwartorzędu (eds. W. Ciężkowski, J. Wojewoda and A. Żelaźniewicz): 169-182. WIND, Wrocław.

Plumlee, G., Whitehouse-Veaux, P., 1994. Mineralogy, paragenesis, and mineral zoning of the Bulldog Mountain vein system, Creede District, Colorado. Economic Geology, 89: 1883-1905.

Pršek, J., Mederski, S., Kowalczyk, D., 2019. Ag-Sb-Pb-Cd mineral paragenesis in the barite veins: example from the Sowie Mountains, Poland. Life with Ore Deposits on Earth. 15th Biennial SGA Meeting, 27-30 August 2019, Glasgow, 1: 455-458.

Sack, R.O., Goodell, P.C., 2002. Retrograde reactions involving galena and Ag-sulphosalts in a zoned ore deposit, Julcani, Peru. Mineralogical Magazine, 66: 1043-1062.

Sack, R.O., Lynch, J.V.G., Foit, F., 2003. Fahlore as a petrogenetic indicator: Keno Hill Ag-Pb-Zn District, Yukon, Canada. Mineralogical Magazine, 67: 1023-1038.

Scharrer, M., Kreissl, S., MarkI, G., 2019. The mineralogical variability of hydrothermal native element-arsenide (five-element) 
associations and the role of physicochemical and kinetic factors concerning sulfur and arsenic. Ore Geology Reviews, 113: $1-28$.

Sejkora, J., Kopecký, S., Pauliš, P., 2015. New knowledges of primary mineralization in the ore district Havličkủv Brod (Czech Republic) (in Czech with English summary). Bulletin Mineralogicko-petrologického oddělení Národního Muzea v Praze, 23: 277-296.

Sejkora, J., Krištůfek, M., Pauliš, P., Jakobec, K., 2016. Sulfide mineralization from Skalka near Kraslice (Czech Republic) (in Czech with English summary). Bulletin Mineralogicko-petrologického oddělení Národního Muzea v Praze, 24: 278-284.

Shalaby, I.M., Stumpfl, E., Helmy, H.M., El Mahallawi, M.M., Kamel, O.A., 2004. Silver and silver-bearing minerals at the Um Samiuki volcanogenic massive sulphide deposit, Eastern Desert, Egypt. Mineralium Deposita, 39: 608-621.

Siuda, R., 2012. Silver minerals from Friederike Juliane Mine at Ciechanowice (Sudety Mts, Poland) (in Polish with English sum- mary). Biuletyn Państwowego Instytutu Geologicznego, 448: 315-324.

Števko, M., Sejkora, J., Peterec, D., 2015. Grumiplucite from the Rudnany deposit, Slovakia: a second world-occurrence and new data. Journal of Geosciences, 60: 269-281.

Traube, H., 1888. Die Minerale Schlesiens. JU Kern, Wrocław.

Velebil, D., 2014. Contribution to knowledge of chemistry of mercurian tetrahedrites: localities Jedová hora (Czech Republic), Rudňany, Rožňava, Nižná Slaná, Slovinky (Slovakia) and Maškara (Bosnia and Herzegovina) (in Czech with English summary). Bulletin Mineralogicko-petrologického Oddělení Národního Muzea v Praze, 22: 131-143.

Żelaźniewicz, A., Aleksandrowski, P., Buła, Z., Konon, A., Oszczypko, N., Ślączka, A., Żaba, J., Żytko, K., 2011. Tectonic regionalization of Poland (in Polish). Komitet Nauk Geologicznych PAN, Wrocław. 


\title{
Geochemistry and geochronology of the Jawornik granitoids, Orlica-Śnieżnik Dome, Sudetes, Poland
}

\author{
Dawid BIAŁEK ${ }^{1, *}$ \\ 1 University of Wrocław, Institute of Geological Sciences, pl. M. Borna 9, 50-204 Wrocław, Poland
}

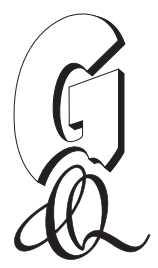

Białek, D., 2020. Geochemistry and geochronology of the Jawornik granitoids, Orlica-Śnieżnik Dome, Sudetes, Poland. Geological Quarterly, 64 (4): 000-000, doi: 10.7306/gq.1567

Associate Editor: Leszek Krzemiński

The Jawornik granitoids intrude, in vein-like form, a sequence of a polymetamorphic metavolcanic and metapelitic rocks of the Orlica-Śnieżnik Dome, Sudetes, Poland. This paper provides whole-rock geochemical data, sensitive high-resolution ion microprobe (SHRIMP) U-Pb zircon geochronological data as well as ${ }^{40} \mathrm{Ar}-{ }^{39} \mathrm{Ar}$ age determinations to constrain the genetic and temporal relationships of the different rock types forming these veins. Based on macroscopically visible features of the granitoids and their relationship with tectonic structures visible in the country rocks, four varieties of the Jawornik granitoids have been distinguished: amphibole- and biotite-bearing granites (HBG), biotite-bearing granites (BG), biotite- and muscovite-bearing granites (BMG) and muscovite-bearing granites (MG). The Jawornik granitoids as a whole show a limited but significant variation in major element chemical composition, with $\mathrm{SiO}_{2}$ ranging from 65 to 76 wt. \% (average 69.16 wt. $\%$, $\mathrm{n}=$ 24). They are subalkalic, peraluminous and calc-alkaline [average $\mathrm{A} / \mathrm{CNK}=1.07$, average $\left(\mathrm{Na}_{2} \mathrm{O}+\mathrm{K}_{2} \mathrm{O}\right)=7.75$, average $\left(\mathrm{Fe}_{2} \mathrm{O}_{3}{ }^{\mathrm{t}} /\left(\mathrm{Fe}_{2} \mathrm{O}_{3}{ }^{\mathrm{t}}+\mathrm{MgO}\right)=0.59\right]$. Close inspection of their geochemical parameters showed that the samples investigated can be subdivided into two groups. The first group, the HBG, BG, and BMG varieties, comprising most of the granitoids in the Złoty Stok-Skrzynka Tectonic Zone, were formed by melting of greywackes or/and amphibolites. The MG, belonging to the second group, were formed by partial melting of a more felsic source. The HBG yielded a zircon U-Pb age of $351 \pm 1.3 \mathrm{Ma}$ and well-defined ${ }^{40} \mathrm{Ar}^{39} \mathrm{Ar}$ plateau ages for hornblende $(351.1 \pm 3.9 \mathrm{Ma})$ and coexisting biotite (349.6 $\left.\pm 3.8 \mathrm{Ma}\right)$, indicating probably the oldest magmatic event in this region. Zircons from the MG, the youngest rock variety on the basis of their relationship with the tectonic structures in the host rocks, yielded a $\mathrm{U}-\mathrm{Pb}$ age of $336.3 \pm 2.4 \mathrm{Ma}$, though based on three points only. The biotites and muscovites from the BMG have ${ }^{40} \mathrm{Ar}-{ }^{39} \mathrm{Ar}$ plateau ages of $344.1 \pm 4.7 \mathrm{Ma}$ and $344.6 \pm 3.8 \mathrm{Ma}$, respectively. These data, in combination with already published isotopic ages, suggest that the Jawornik granitoids intruded host rocks of the Orlica-Śnieżnik Dome in three stages, at 350, 344 and 335 Ma.

Key words: Jawornik granitoids, geochemistry, geochronology, Sudetes, Variscan granitoids.

INTRODUCTION

The Sudetes, located in southwestern Poland, northeastern Bohemia and northern Moravia, represent a small portion of the Variscan Orogenic Belt in Europe and form the NE part of the Bohemian Massif (Fig. 1). Geological units, belonging to all four major lithotectonic domains of the Bohemian Massif (i.e. Saxothuringian, Teplá-Barrandian, Moldanubian and Brunovistulian domains), make up the complex structural mosaic of the Sudetes (Matte et al., 1990; Cymerman et al., 1997; Franke, 2000; Franke and Żelaźniewicz, 2002; Mazur et al., 2006, 2015; Schulmann et al., 2014). The assembly of these units occurred during Late Devonian to Early Carboniferous terrane collisions (e.g., Matte et al., 1990; Cymerman et al.,

*E-mail: dawid.bialek@uwr.edu.pl

Received: March 6, 2020; accepted: July 30, 2020; first published online: October 30, 2020
1997; Aleksandrowski and Mazur, 2002); the Variscan granitoids form a portion of the rock inventory in all of them. They differ in age, composition and their tectonic context. The Bohemian Massif is an example of a hot orogen with numerous compositionally diversified granitoid plutons. The plutonism was active for nearly $80 \mathrm{My}$, and on the basis of their tectonic settings, age and petrogenesis, four groups of plutons have been distinguished (Žák et al., 2014). The oldest ( 375 Ma), volumetrically small, granitoid bodies, are subduction-related, connected with early stages of plate collision. Plutons belonging to the next two groups (354-346 Ma and 340-335 Ma) were emplaced during consecutive phases of orogenic deformation. In the fourth group there are plutons emplaced during final stages of the Variscan orogeny (330-320 Ma) and postorogenically $(\sim 300 \mathrm{Ma})$. The largest Sudetic plutons - the Karkonosze Pluton, Strzegom-Sobótka Massif, Žulowá Pluton, and small intrusions that crop out in the Strzelin Massif, emplaced on the periphery of the Variscan orogen, can be classified as late- to post-tectonic (Oberc-Dziedzic and Kryza, 2012; Kryza et al., 2014; Laurent et al., 2014; Turniak et al., 2014). Older and smaller granitoids of the central Sudetes are spatially 